\title{
CORRESPONDENCE
}

\section{Herczynski's arrest}

SIR - Many of your readers will have been dismayed to learn from Vera Rich's note (Nature 20 May, p.172) that Dr Ryszard Herczynski has been arrested in Warsaw for passing to two attaches from the US Embassy "materials damaging to the interests of the Polish state". Herczynski's numerous friends in this country know him as a vigorous and fearless critic of attempts by the authorities in Poland to inject political considerations into the conduct of scientific and academic affairs. That he has been critical of action taken under the present martial law, we can be sure; and it is probable that the materials alleged to be damaging to the interests of the Polish state were simply documents expressing such criticisms. Nevertheless, he could be sentenced to between three and five years' imprisonment (not internment) under martial law, with no appeal. This would be a terrible injustice.

Expressions of support for Herczynski from Western scientists may dissuade the Polish government from treating him harshly. It would be helpful to convey to those concerned that the essentially non-political causes defended by Herczynski - respect for the truth in scientific and academic matters and maintenance of the integrity of scientists are also our causes, and that we do indeed care what happens to him. Quick action is desirable since Herczynski's trial may be held soon.

A letter of protest has been sent to the

Polish authorities, signed by 25 scientists.

G.K. BATCHELOR

Department of Applied Mathematics and

Theoretical Physics,

Cambridge, UK

\section{Japanese IQ}

SIR - Reading Alun Anderson's comments on the study of IQ in Japan (Nature 20 May, p.180), the surprising find is not that it has improved with better nutrition, urbanization, improved social conditions and so on, but that under conditions comparable with those in the United States and Europe, it is 10-15 per cent higher. If this difference is genuine, I could offer an easily testable explanation.

It is well known that ceaching can improve IQ results by $5-10$ per cent. My conjecture is that every Japanese child undergoes a sort of coaching when (s)he learns to read and write his own language. Apparently it is so complex that only by the age of eleven can they be regarded as fully literate. Of course, the ideal IQ tests are language neutral, but my point is that the mastering of a difficult language plays a general IQ boosting role. This hypothesis is easily testable: one should compare the IQs of immigrant Japanese groups in the United States, say, who are literate in their language and matching groups who are not. Also, if the hypothesis is true, other members of the Chinese-related cultures should show higher $\mathrm{IQ}$, under similar social and economic conditions.

Finally, competent linguists could perhaps find other languages of comparative complexity, the speakers of which could then be included in such inter-nation IQ comparison.

\section{Drugs and safety}

SIR - I assume that the attack by $\mathbf{M}$. Weatherall (Nature 1 April, p.387) on the toxicological testing of drugs was designed to provoke a response and was not intended to celebrate its publication date.

To propose the substitution of patient surveillance for toxicological testing is at first sight attractive because it places the emphasis firmly on men and women and not rats or bacteria. There is, moreover, undoubtediy a kernel of truth in some of his concern about unthinking and invalid testing, yet in selecting genetic toxicology to bear the brunt of his criticism he has chosen unwisely. His arguments show ignorance of current attitudes among thinking toxicologists and regulators. Moreover, the effects under consideration are, as I shall show, almost completely refractory to conventional surveillance.

Genetic toxicologists aim to detect potential mutagens and initiators of carcinogenesis. They would not expect that the result of a bacterial mutagenicity test alone could be extrapolated directly to man. Properly thought-out tests carried out early in the development of a drug can give an alert to possible problems ahead, problems that may be averted by chemical modification or that may require specialized tests to be undertaken when the drug is first given to humans. It would, of course, be verging on the criminal to give young patients with benign disease a drug known to be a potent mutagen in a wide variety of systems (including whole animal tests). Nevertheless, weak mutagens, or those active only in certain rather special situations, may well have a clinical future when all relevant circumstances have been considered. It is here (at the regulatory level) that the common sense advocated by Weatherall should be seen to operate.

To argue for surveillance and against testing for mutagenicity is particularly inappropriate since the deleterious effects of DNA damage are in general so long delayed that they would fail to be detected. Although sensitive techniques are now being developed that would enable the presence of DNA damage and other markers indicative of DNA damage to be detected in treated patients, their use is justifiable on economic grounds only where mutagenicity tests indicate possible risk.

Weatherall is right to try to educate the public and their regulatory bodies. not to expect absolute safety from drugs any more than from surgical operations, but the surgeon introducing a new technique will have spent many hours experimenting on animals and will have a fair idea of possible risks before his first operation on a patient. $\quad$ B.A. BRIDGES

MRC Cell Mutation Unit, University of Sussex, Brighton, UK

\section{Back to basics}

SIR - Many American scientists may be unconvinced that "Europe leads on (nucleotide) sequences' as suggested by your correspondent Robert Walgate in his article on the European Molecular Biology Laboratory (EMBL) computer library of nucleic acid sequences (Nature 15 April, p.596). American molecular biologists have for several years been successfully using several similar data banks including the Nucleic Acid Sequence Data Base organized by Margaret Dayhoff's group at Georgetown University Medical Center. This sequence library, in addition to containing several programs for sequence analysis, currently includes 746,000 nucleotides (compared with the 600,000 reported in your article for the EMBL library).

Apart from the issue of nucleotide quantity, the sample entry provided in your article, while perhaps not typical, does not reflect favourably on the EMBL library as regards quality. The entry gives no indication that the MOPC41 kappa gene sequence presented was not determined by the authors of the entry reference; the sequence was in fact copied by them in their paper to compare with a sequence of another gene which they had determined. In transcribing the MOPC41 sequence these authors erroneously inserted a nucleotide (position 189) which now appears in the EMBL sequence. This trivial error illustrates the importance of relying on original sources of sequence data, a policy of the Georgetown data base. The correct sequence is included in the corresponding entry from the Georgetown data base (see below) along with the correct primary reference (Seidman et al. Nature 280, 370; 1979).

JoNATHAN SEIDMAN EDWARD E. Max

Department of Health \& Human Services, National Insitutes of Health, Bethesda, Maryland, USA

$$
\begin{aligned}
& \text { Is kapra chain } U \text { resion germiline gere UKA1 .. Mouse } \\
& \text { Seidmen, J.E., Mas, E.E., and Leder, F., Nature 280, 370-375, } \\
& 1979 \text { (Fesioues } 1.064 \text { ) } \\
& \text { Residues Feature } \\
& \text { Proteir: Is kafas chain precursor } V \\
& \text { resion MDFC } 41 \\
& \text { omposition: } 168 \mathrm{~A}, 153 \mathrm{C}, 139 \mathrm{G}, 204 \mathrm{~T} \\
& \text { Leristh: } 664 \\
& 10 \quad 20 \quad 30 \quad 40 \quad 50 \quad 60
\end{aligned}
$$

